\title{
Sistema reprodutivo de Anadenanthera peregrina (L.) Speg e Vochysia haenkiana (Spreng.) Mart. em fragmento de cerrado na Chapada dos Guimarães - MT
}

\author{
Reprodutive system of Anadenanthera peregrina and Vochysia haenkiana \\ in a fragment of "Cerrado forest" from Chapada dos Guimarães - MT, \\ Brazil
}

Reginaldo Brito da Costa ${ }^{1}$ Adriana Zanirato Contini ${ }^{2}$ Elaine Silva de Pádua Melo ${ }^{2}$

\section{RESUMO}

O presente estudo objetivou avaliar o sistema reprodutivo das espécies Anadenanthera peregrina (L.) Speg. e Vochysia haenkiana (Spreng.) Mart. Foram estudados aspectos do sistema de cruzamento, complementados pelas observações de maturação dos frutos e a germinação das sementes em função dos tipos de cruzamentos testados. As sindromes de dispersão das sementes foram também avaliadas através das características morfológicas dos frutos e sementes. $O$ estudo foi realizado em um fragmento de cerrado com aproximadamente 32 ha, no municipio de Chapada dos Guimarães, $M T$, a $15^{\circ} 10^{\prime} \mathrm{S}, 55^{\circ} 35^{\prime} \mathrm{W}$, e à altitude de $450 \mathrm{~m}$. $\mathrm{O}$ delineamento experimental utilizado na determinação do sistema de cruzamento para cada espécie foi o de blocos ao acaso, com seis tratamentos para a espécie Vochysia haenkiana e cinco tratamentos para Anadenanthera peregrina, ambas com três repetições. O sistema de cruzamento detectado para as duas espécies foi o preferencialmente alogâmico, porém, com a possibilidade, não desprezivel, de produção de frutos/ sementes por autofertilização, sugerindo um aumento gradual de autocompatibilidade genética como estratégia de geração de descendência no ambiente florestal fragmentado. A polinização cruzada em Anadenanthera peregrina é favorecida tanto pelo alto grau de auto-incompatibilidade genética quanto pela protandria detectada. O padrão de maturação dos frutos e sementes e o periodo de dispersão das sementes foram distintos em ambas as espécies, ocorrendo, entretanto, durante ou no final da estação seca, facilitando a distribuição dos propágulos anemocóricos. A germinação em ambas as espécies foi rápida $e$ em alta percentagem.

Palavras-chave: fragmentação florestal, angico branco, cambarazinho.

\begin{abstract}
The study of the breeding system of Anadenanthera peregrina (L.) Speg. and Vochysia haenkiana (Spreng.) Mart. was the main purpose of this work. It was also studied fruit maturation, seed dispersal and seed germination to characterize the reproductive system of these two species. Field work was carried out in a fragment of cerrado forest from Chapada dos Guimarães-MT $\left(15^{\circ} 10^{\prime} \mathrm{S}, 55^{\circ} 35^{\prime} \mathrm{W}\right)$, with an altitude of $450 \mathrm{~m}$. Date analyses followed the randomized block design, with. six treatments for Vochysia haenkiana and five treatments for Anadenanthera peregrina, each treatment replicated three individuals. Both species showed a breeding system preferably xenogamic (cross-pollination), but fruit production by autogamy suggests a gradual increase of genetic selfcompatibility as a strategy for maintenance of progeny presence in fragmented forest environment. The degree of genetic selfincompatibility demonstrated by Anadenanthera peregrina is favoured by its dicogamy patterns that promotes crosspollination. Fruit maturation and seed dispersal pattern, were different for each species, and were observed during or at the end of the dry season, making seed dispersal of anemocoric propagules more effective. Germination was fast and observed in a high percentage of seeds from both species.
\end{abstract}

Key words: forest fragmentation, angico branco, cambarazinho.

\section{INTRODUÇÃO}

O cerrado compõe-se de uma formação vegetal que, originalmente, ocupava cerca de dois

\footnotetext{
${ }^{1}$ Engenheiro Florestal, D.Sc,Universidade Católica Dom Bosco (UCDB), Programa Desenvolvimento Local, CP 100, 79117-900, Campo Grande, MS. E-mail: rcosta@ucdb.br Autor para correspondência.

${ }^{2}$ Acadêmicas do Curso de Biologia da Universidade Católica Dom Bosco (UCDB), bolsistas CNPq.
} 
milhões de quilômetros quadrados do território brasileiro. As estimativas atuais apontam para uma perda total estimada entre 37\% (DIAS, 1993) e 50\% (SILVA JÚNIOR, 1997). Embora presente em uma vasta extensão do Brasil e, apesar de todos os estudos, pouco ainda se conhece sobre este tipo de vegetação que está paulatinamente desaparecendo em função da expansão da fronteira agrícola.

A exemplo de outros tipos de vegetação brasileira, como as matas do norte do Paraná e a Mata Atlântica, as áreas de cerrado estão sujeitas à exploração indiscriminada, correndo-se o risco de se devastar completamente grandes áreas, sem a preocupação de conhecer um pouco mais a vegetação ali existente, tendo este modelo exploratório produzido a fragmentação dos ecossistemas. Neste sentido, muitos estudiosos ligados à pesquisa do cerrado preconizam a necessidade de estudos para entender os mais diversos aspectos das inúmeras espécies deste bioma.

A fragmentação de ecossistemas está diretamente relacionada a dinâmica de uso da terra em áreas urbanas e rurais, em particular. Assim, a fragmentação tornou-se um processo "lógico" de uso dos recursos naturais por fazendeiros e comunidades locais (VIANA, 1995). Esta questão está evidenciada em diversos estudos sobre os efeitos da fragmentação de ecossistemas (LEVIN \& KERSTER, 1974; PLATT \& WEISS, 1985; SCHEMSKE et al., 1994 e SCARIOT, 1999).

A espécie Anadenanthera peregrina vegeta em matas semidecíduas e na transição para o cerrado, sendo a sua madeira muito pesada, dura e de textura média, com ocorrência natural desde o estado do Tocantins até o estado do Rio de Janeiro (LORENZI, 1998). Vochysia haenkeana ocorre nos estados de Mato Grosso do Sul, Goiás e Mato Grosso, na mata latifoliada semidecídua (LORENZI, 1998), sendo a madeira indicada para uso interno em construção civil, bem como, na confecção de móveis, cabos de ferramentas e instrumentos agrícolas.

Alguns trabalhos, dentre eles os de BAWA (1974), JANZEN (1980), CATHARINO et al. (1982), CRESTANA et al. (1982), BAKER et al. (1983), SCHEMSKE et al. (1994), BARBOSA (1983), ARROYO \& USLAR (1993), ARMSTRONG \& MARSH (1997), BARBOSA (1997) e BORGES (2000), abordando aspectos particulares de biologia floral, sistema de cruzamento e interações entre animais e plantas, trouxeram informações muito valiosas, porém, outras pesquisas devem ser efetuadas, pois diversos aspectos ainda não foram estudados, especialmente em ambientes fragmentados.
Neste contexto, este trabalho visou avaliar o sistema reprodutivo das espécies Anadenanthera peregrina e Vochysia haenkiana, contribuindo para a ampliação do conhecimento das espécies, que estão em constante pressão antrópica em fragmentos florestais, tendo em vista que a reprodução está intimamente ligada à constituição, estrutura, distribuição e desenvolvimento de comunidades arbóreas.

\section{MATERIALEMÉTODOS}

O estudo foi realizado em área de cerrado na Fazenda Invernada, com área total de 735,50 ha, no município de Chapada dos Guimarães, MT. A área na qual as espécies foram estudadas trata-se de um fragmento de floresta nativa de aproximadamente 32 ha, localizada a $15^{\circ} 10^{\prime} \mathrm{S}, 55^{\circ} 35^{\prime} \mathrm{W}$ e altitude de $450 \mathrm{~m}$. A temperatura média anual é de $21^{\circ} \mathrm{C}$ e a pluviosidade média anual é de $1480 \mathrm{~mm}$ (BRASIL, 1982). Segundo a classificação de Köpen, o clima é do tipo Aw, com predominância de verão úmido e um período de inverno seco com temperaturas e precipitações pluviais mais reduzidas. A vegetação local é representada pela savana arbórea aberta com floresta de galeria. O solo predominante é classificado como areia quatzosa álica distrófica.

Para a aplicação dos tratamentos visando a determinação do sistema de cruzamento das espécies, considerou-se como período de floração, o espaço de tempo desde o aparecimento dos primeiros botões florais até a queda das últimas pétalas; período de frutificação, desde o início do desenvolvimento dos frutos até a maturação completa e conseqüente dispersão das sementes.

Os processos de maturação dos frutos, bem como a dispersão das sementes, foram observados no campo, com o objetivo de avaliar possíveis interações bióticas. Os dados de comprimento dos frutos até a maturação foram anotados quinzenalmente.

A antese, definida por FAEGRI \& VAN DER PIJL (1979) como o início do período em que a flor expõe a antera e estigma aos agentes polinizadores, foi observada no campo, bem como em amostras de vinte flores de cada espécie em vários estágios de desenvolvimento, examinadas em laboratório para detecção de diferenças morfológicas entre elas. Observou-se, também, a presença de grãos de pólen aderidos à superfície do estigma.

O sistema de cruzamento de cada espécie foi estudado em experimentos de campo. Os tratamentos testados foram os seguintes: a)Polinização aberta - controle (PAB) - os ramos com botões florais 
foram marcados e anotado o número total de botões; b)Polinização cruzada (PCR) - as flores foram emasculadas quando do isolamento e o pólen coletado de outro indivíduo da mesma espécie e realizada a polinização manualmente, usando-se pincel; c)Fechada com filó (FFI) - as flores foram emasculadas e isoladas em sacos de filó; desta forma passaria o vento com pólen, porém não os insetos; d)Autopolinização com pólen da mesma árvore (AMA) - as flores foram emasculadas e ensacadas com tecido não tramado no momento da antese e polinizadas manualmente com pólen da própria árvore; e)Autopolinização com pólen da mesma flor (AMF) - as flores foram ensacadas com tecido sem costura no dia anterior à antese e mantidas assim durante o período receptivo; f)Agamospermia (AGA) - as flores foram emasculadas e ensacadas no momento da antese para verificar possíveis mecanismos de apomixia.

A época de aplicação dos tratamentos foi aquela de máxima floração das espécies durante o ano, levando-se em consideração o início da abertura das flores para que não ocorressem polinizações indesejáveis. As flores foram tomadas ao acaso nos ramos, no período de antese máxima durante o dia de aplicação dos tratamentos. O número de flores utilizadas foi sempre igual em cada ramo do indivíduo da mesma espécie. O número diferente de flores utilizadas nos tratamentos ocorreu em função da disponibilidade de flores recém abertas no momento da polinização manual, e a existência de protandria para a espécie Anadenanthera peregrina.

O delineamento experimental utilizado para cada espécie foi o de blocos ao acaso, considerando cada indivíduo arbóreo da espécie como um bloco com três repetições, seis tratamentos para Vochysia haenkiana cinco tratamentos para An a d e n a n thera peregrina (em função da protandria, não foi testado o tratamento AMF nesta espécie). Os ramos de cada indivíduo constituíram-se em parcelas, distribuídas espacialmente em diferentes pontos em torno da copa das árvores, sorteados de um número $\mathrm{AGA}=$ Agamospermia . de vinte ramos floríferos, obtendo-se seis ramos representativosdo indivíduo arbóreo, contendo cada parcela o mesmo número de flores. As médias de produção de frutos em percentagem (\%) dos tratamentos foram comparadas pelo teste de Tukey a $1 \%$ de significância. Os valores utilizados nas análises de variância foram previamente transformados em $\operatorname{arcsen} \sqrt{x+0,5 / 100}$.

Os dados referentes ao parâmetro germinação das sementes dos tratamentos PAB e PCR foram analisados pelo teste $\mathrm{t}$ pareado a $5 \%$ de probabilidade de erro (COUTO, 1979). Utilizaram-se no teste, sementes obtidas de frutos de um mesmo ramo, mas que se originaram de flores submetidas a diferentes tratamentos.

\section{RESULTADOS E DISCUSSÃO}

Na tabela 1 , estão contidos os resultados de produção de frutos em função do número de flores marcadas. Apresenta, ainda, resultados do número médio de sementes produzidas por fruto. Evidenciamse, nesta tabela, tratamentos de polinização aberta (PAB) e de polinização cruzada (PCR), pela elevada relação frutos/flores frente aos demais tratamentos.

Para a espécie Anadenanthera peregrina, a protandria, considerada como adaptação floral que favorece a polinização cruzada (BAKER et al., 1983), é reforçada por um alto grau de auto-incompatibilidade genética (Tabela 1). A ocorrência de protandria em outras espécies é relatada por BAWA (1974), McDADE (1986) e CRESTANA et al. (1982).

Para a espécie Vochysia haenkiana, os resultados de produção de frutos evidenciam também cruzamentos testados.

\begin{tabular}{|c|c|c|c|c|c|}
\hline \multirow{2}{*}{ Espécie } & \multirow{2}{*}{ Tratamentos* } & \multicolumn{2}{|c|}{ T O T A I S } & \multirow{2}{*}{$\begin{array}{c}\text { Frutos/Flores } \\
(\%)\end{array}$} & \multirow{2}{*}{$\begin{array}{l}\mathrm{N}^{\mathrm{o}} \text { médio de sementes } \\
\text { produzidas/fruto }\end{array}$} \\
\hline & & $\mathrm{N}^{\mathrm{o}}$ de flores & $\mathrm{N}^{\mathrm{o}}$ de frutos & & \\
\hline \multirow{5}{*}{$\begin{array}{l}\text { Anadenanthera } \\
\text { Peregrina }\end{array}$} & PAB & 624 & 488 & 78,20 & 5,60 \\
\hline & PCR & 63 & 51 & 80,95 & 6,05 \\
\hline & FFI & 132 & 00 & 0,0 & - \\
\hline & AMA & 61 & 06 & 9,84 & 2,03 \\
\hline & AGA & 183 & 00 & 0,0 & - \\
\hline \multirow{6}{*}{$\begin{array}{l}\text { Vochysia } \\
\text { haenkiana }\end{array}$} & PAB & 501 & 407 & 81,24 & 2,71 \\
\hline & PCR & 42 & 36 & 85,71 & 2,78 \\
\hline & FFI & 215 & 00 & 0,0 & - \\
\hline & AMA & 46 & 05 & 10,87 & 2,42 \\
\hline & $\mathrm{AMF}$ & 40 & 03 & 7,50 & 2,46 \\
\hline & AGA & 189 & 00 & 0,0 & - \\
\hline
\end{tabular}

*PAB = Polinização aberta (controle) PCR = Polinização cruzada; FFI = Fechada com filó; AMA = Autopolinização com pólen da mesma árvore; $\mathrm{AMF}=$ Autopolinização com pólen da mesma flor; 
um grau expressivo de auto-incompatibilidade genética, porém não se observou defasagem no tempo de atividade dos órgãos masculinos e femininos.

Deve-se, entretanto, destacar, no contexto desta discussão, a obtenção de frutos provenientes de autopolinização, especialmente com pólen da mesma árvore: Anadenanthera peregrina (9,84\%) e Vochysia haenkiana (10,87\%) (Tabela 1). Estes dados remetem para a questão da fragmentação florestal, com a conseqüente diminuição do tamanho efetivo populacional (FUTUYMA, 1997 e COSTA et al., 2000). Isto pode provocar na população o aumento gradual de autocompatibilidade genética como uma estratégia de geração de descendência, com tendência a um sistema reprodutivo misto. Esta é uma situação que deve ser monitorada sistematicamente em ambientes florestais fragmentados, tendo em vista a manutenção da variabilidade genética das populações.

Os resultados da análise de variância para as médias de produção de frutos contidas na tabela 2 completam os dados do tabela 1, e demonstram que estatisticamente há diferença altamente significativa entre tratamentos, tendo em vista, principalmente, as percentagens mais expressivas dos tratamentos PAB e PCR em relação aos demais.
Tabela 2 - Resultados da análises de variâncias e do teste de Tukey, para a variável produção de frutos $(\%)$, em função das espécies e dos tipos de cruzamentos testados.

\begin{tabular}{lcc}
\hline \multirow{2}{*}{ Tratamento } & \multicolumn{2}{c}{ E S P É C I E S } \\
\cline { 2 - 3 } Floral $^{*}$ & $\begin{array}{c}\text { Anadenanthera } \\
\text { peregrina }\end{array}$ & $\begin{array}{c}\text { Vochysia } \\
\text { haenkiana }\end{array}$ \\
\hline PAB & $78,20 \mathrm{a}^{1}$ & $81,24 \mathrm{a}$ \\
PCR & $80,95 \mathrm{a}$ & $85,71 \mathrm{a}$ \\
FFI & $0,0 \mathrm{c}$ & $0,0 \mathrm{c}$ \\
AMA & $9,84 \mathrm{~b}$ & $10,87 \mathrm{~b}$ \\
AMF & - & $7,50 \mathrm{~b}$ \\
AGA & $0,0 \mathrm{c}$ & $0,0 \mathrm{c}$ \\
\hline MÉDIA GERAL & 33,80 & 30,89 \\
CV (\%) & 5,18 & 11,32 \\
F para tratamento & $2484,01 * *$ & $162,31 * *$ \\
\hline
\end{tabular}

*PAB = polinização aberta (controle); $\mathrm{PCR}=$ polinização cruzada; FFI = fechada com filó; AMA = autopolinização com pólen da mesma árvore; $\mathrm{AMF}=$ Autopolinização com pólen da mesma flor; AGA = agamospermia.

** significativo ao nível de $1 \%$ pelo teste de $\mathrm{F}$.

${ }^{1}$ médias na mesma coluna não seguidas pela mesma letra diferem estatisticamente pelo teste de Tukey em nível de 5\% de significância.

Os resultados caracterizam um sistema de cruzamento preferencialmente alogâmico para as duas espécies, porém com a possibilidade de produção de sementes por autogamia .

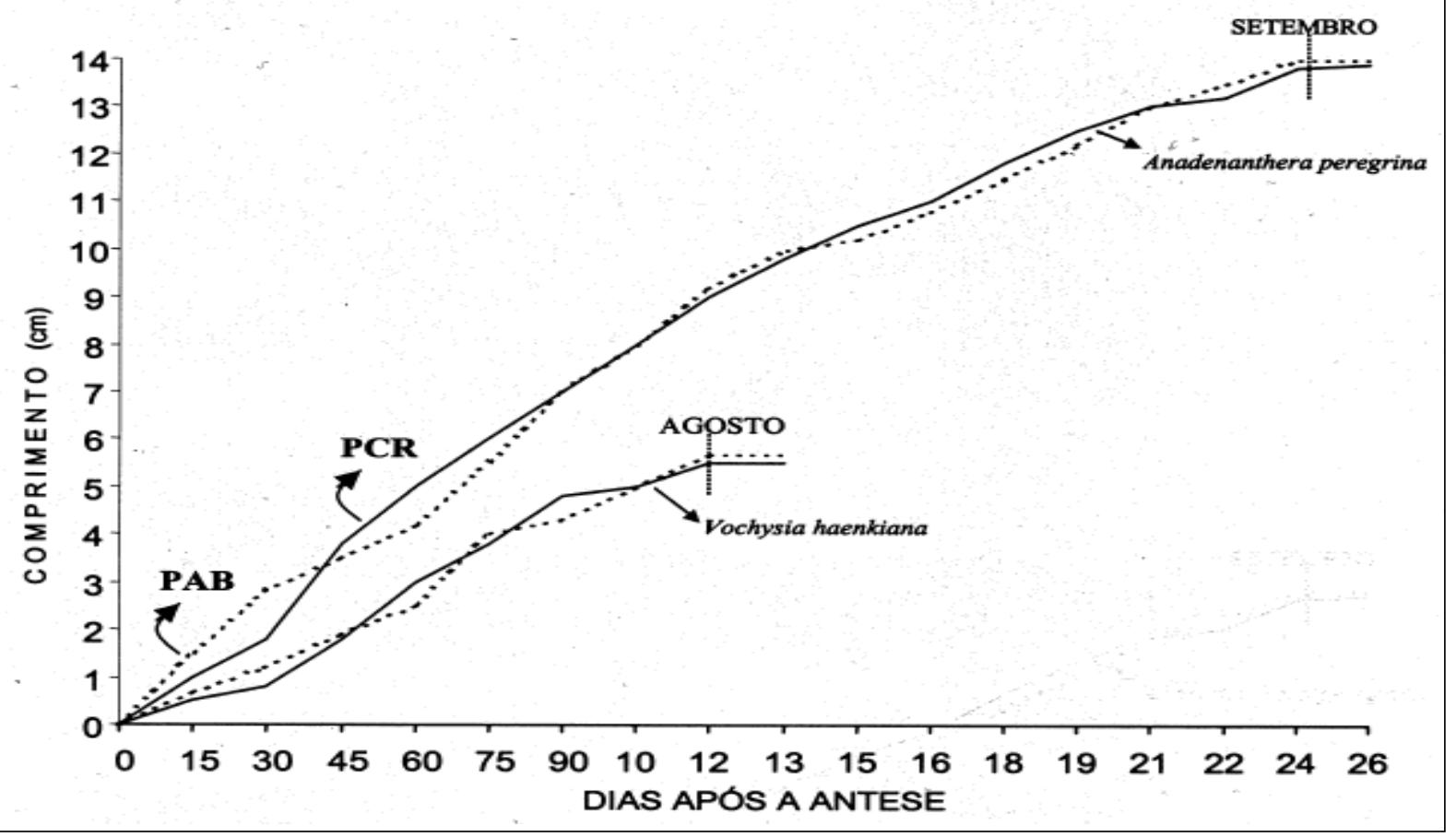

Figura 1 - Desenvolvimento de frutos de Anadenanthera peregrina e Vochysia haenkiana.

Ciência Rural, v. 33, n. 2, mar-abr, 2003. 
A época de maturação dos frutos $\mathrm{e}$ das sementes de Anadenanthera peregrina coincide com o final da estação seca (Figura 1), quando diversas espécies do cerrado estão com poucas folhas. A espécie apresenta frutos secos, deiscentes, sem atrativos para os animais. São legumes achatados que se abrem apenas de um lado, expondo suas sementes que caem imediatamente após a deiscência dos frutos. As sementes são leves, achatadas, escuras, discóides, de formato orbicular. A sua morfologia permite que sejam dispersas por vento forte a curtas distâncias, porém, com maior freqüência, estabelecem-se junto à árvore matriz, ficando caracterizada para esta espécie a síndrome barocórica.

Os frutos de Vochysia haenkiana são capsulares, de formato ovóide, sem atrativos para animais. $\mathrm{O}$ tamanho é de aproximadamente $3 \mathrm{~cm}$, abrindo-se paulatinamente a partir do ápice, expondo suas sementes, em geral em número de 3 , que caem imediatamente após a abertura ou durante a ocorrência de ventos mais fortes. As sementes são leves, achatadas e aladas. A sua morfologia permite que sejam dispersadas pelo vento a curtas distâncias (aproximadamente $5 \mathrm{~m}$ ), ou a distâncias maiores (100 $\mathrm{m}$ ), por ocasião de ventos mais fortes. Assim, fica caracterizada para esta espécie a síndrome anemocórica. A dispersão das sementes ocorre num período em que o índice de precipitação é mínimo (agosto). Para a dispersão de diásporas anemocóricas é uma época ideal, tendo em vista a maior incidência de ventos e o desfolhamento de inúmeras espécies.

As sementes produzidas nos tratamentos de polinização aberta (PAB) e polinização cruzada (PCR), germinaram com rapidez e em percentagem elevada sob condições de laboratório, como mostram as figuras $2 \mathrm{a}$ e $2 \mathrm{~b}$, respectivamente para Anadenanthera peregrina e Vochysia haenkiana.
Embora os resultados, em termos percentuais, sejam expressivos, para ambas as espécies, o tratamento $\mathrm{PAB}$ apresentou valores levemente inferiores comparados ao tratamento PCR. A análise estatística, realizada através do teste t pareado, não detectou diferença significativa a $5 \%$ de significância.

\section{CONCLUSÕES}

O sistema de cruzamento detectado para as duas espécies foi o preferencialmente alogâmico, porém, com a possibilidade, não desprezível, de produção de sementes por autogamia, isto pode sugerir um aumento gradual de autocompatibilidade genética como estratégia de geração de descendência em ambiente florestal fragmentado.

A polinização cruzada em Anadenanthera peregrina é favorecida tanto pelo alto grau de autoincompatibilidade genética quanto pela protandria detectada.

O padrão de maturação dos frutos e sementes, bem como o período de dispersão das diásporas foram distintos para as duas espécies, ocorrendo, entretanto, durante ou no final da estação seca, facilitando a distribuição dos propágulos anemocóricos de Vochysia haenkiana. A germinação ocorreu, em ambas as espécies, de forma rápida e em alta percentagem.

Ciência Rural, v. 33, n. 2, mar-abr, 2003. 


\section{REFERÊNCIASBIBLIOGRÁFICAS}

ARMSTRONG, J.E.; MARSH, D. Floral herbivory, floral phenology, visitation rate, and fruit set in Anaxagorea crassipetala (Annonaceae), a lowland rain forest tree of Costa Rica. Journal of the Torrey Botanical Society, v.124, n.3, p.228-235, 1997.

ARROYO, M.T.K.; USLAR P. Breeding systems in a temperate mediterranean-type climatemontane sclerophyllous forest in Central Chile. Botanical Journal of the Linnean Society, v.111, p. 83-102, 1993.

BAKER, H.G. et al. Breeding systems. In: GOLLEY, F. B. Tropical rain forest ecossistems structure and function. Amsterdan : Elsevier, 1983. p.189-216.

BARBOSA, A.A.A. Aspectos da ecologia reprodutiva de três espécies de Qualea (Vochysiaceae) em cerrado de Brasília. 1983. 92f. Dissertação (Mestrado em Biologia Vegetal) - Curso de Pós-graduação em Biologia, Universidade de Brasília.

BARBOSA, A.A.A. Biologia reprodutiva de uma comunidade de campo sujo, Uberlândia - MG. 1997. 180f. Tese (Doutorado em Biologia Vegetal) - Curso de Pós-graduação em Biologia, Universidade Estadual de Campinas.

BAWA, K.S. Breeding systems of tree species of a lowland tropical community. Evolution v.28, p.85-92, 1974.

BORGES, H.B.N. Biologia reprodutiva e conservação do estrato lenhoso numa comunidade do cerrado. 2000. 158f. Tese (Doutorado em Biologia Vegetal) - Curso de Pós-graduação em Biologia, Universidade Estadual de Campinas.

BRASIL, Ministério das Minas e Energia. Projeto Radambrasil. Folha SE 21 - Corumbá e SD 21 - Chapada dos Guimarães: geologia, geomorfologia, pedologia, vegetação e uso potencial da terra. Rio de Janeiro, 1982. v.26. 452p.

CATHARINO, E.L.M.; CRESTANA, C. S. M.; KAGEYAMA, P.Y. Biologia floral da Bracatinga (Mimosa scabrella Benth.). Silvicultura, São Paulo, v.16, n.1, p.525-531, 1982.

COSTA, R.B. et al. Maximization of genetic gain in rubber tree (Hevea) breeding with effective size restriction. Genetics and Molecular Biology, v.23, n.2, p.457-462, 2000.

COUTO, H.T.Z. Testes de significância: Teste t: C1-C7. In: IPEF - Práticas experimentais em Silvicultura. Piracicaba, SP : Ed. IPEF, 1979.
CRESTANA, C.S.M.; DIAS, I.S.; KAGEYAMA, P.Y. Biologia floral do guarantã (Esenbeckia leiocarpa Engl.). Silvicultura, São Paulo, v.8, n.28, p.35-38, 1982.

DIAS, B.F.S. Vegetação do cerrado. In: M.N. PINTO (ORG.). Cerrado: caracterização, ocupação e perspectivas. Brasília: Universidade de Brasília - Edunb/Secretaria do Meio Ambiente, Ciência e Tecnologia - SEMATEC, 1993. p.607-663.

FAEGRI, K.; VAN DER PIJL. The principles of polination ecology. 3. ed. Oxford : Pergamon, 1979. 244p.

FUTUYMA, D.J. Biologia evolutiva. 2. ed. Ribeirão Preto: Sociedade Brasileira de Genética/CNPq, 1997. 646p. (Tradução: Mario de Vivo e coordenação: Fábio de Melo Sene).

JANZEN, D.H. Ecologia vegetal nos trópicos. São Paulo: EDUSP, 1980. 79p.

LEVIN, D.A.; KERSTER, H.W. Gene flow in seed plants. Evolutionary Biology, v.7, p.139-220, 1974.

LORENZI, H. Árvores brasileiras: manual de identificação e cultivo de plantas arbóreas nativas do Brasil. 2. ed. Nova Odessa, SP: Ed. Plantarum, 1998. 352p.

McDADE K.A. Protandry, synchronized flowering end sequential phenotypic unisexuality in neotropical Pentagonia macrophylla (Rubiaceae). Oecologia, v.68, p.218-223, 1986.

PLATT, W.J.; WEISS, I.M. An experimental study of competition among invasive prairie plants. Ecology, v.66, p.708-720, 1985.

SCARIOT, A. Forest fragmentation effects on palm diversity in central Amazônia. Journal of Ecology, v.87, p.66-76, 1999.

SCHEMSKE, D.W. et al. Evaluating approaches to the conservation of rare and endangered plants. Ecology, v.75, p.584-606, 1994.

SILVA JÚNIOR, M.C. Endemic bird species and conservation in the cerrado region, South America. Biodiversity and Conservation, v.6, p.435-450, 1997.

VIANA, V.M. Conservação da biodiversidade de fragmentos de florestas tropicais em paisagens intensivamente cultivadas. In: CONFERENCIA INTERNACIONAL: ABORDAGENS INTERDISCIPLINARES PARA A CONSERVAÇÃO DA BIODIVERSIDADE E DINÂMICA DO USO DA TERRA NO NOVO MUNDO, 1995, Belo Horizonte, MG. Anais... Belo Horizonte : Conservation International do Brasil e UFMG, 1995. p.135-154. 